\title{
Accumulation, loss and molecular distribution of cadmium in Mytilus edulis
}

\author{
N. Scholz* \\ Institut für Meereskunde an der Universität Kiel; \\ Düsternbrooker Weg 20, D-2300 Kiel 1, Federal Republic of Germany
}

\begin{abstract}
In Mytilus edulis, accumulation and loss of Cd were analyzed under experimental conditions. Cd uptake by the whole soft body is linear, increasing significantly with increasing $\mathrm{Cd}$ concentrations in the uptake medium. Until $100 \mu \mathrm{g} \mathrm{Cd} \mathrm{l}^{-1}$, neither limitation of uptake nor any saturation process can be observed. Loss of Cd, measured after transfer of experimentally contaminated mussels to natural sea water, is exponential; biological half lives vary between 14 and 29 days. Gills are the primary sites of Cd uptake from the water, whereas in mid-gut gland, kidney, and mantle the uptake is retarded during the first few days. The mid-gut gland not only bears the main body load of $\mathrm{Cd}$, but also shows the highest Cd concentrations. Gel chromatographic studies of midgut gland proteins reveal that $\mathrm{Cd}$ is eluated over the whole molecular weight range. Three metallothionein-like proteins with molecular weights of 6,600,13,200, and 21,000 Dalton could be established. However, they cannot be taken as effective detoxification proteins, because more than $50 \%$ of the accumulated metal is bound to high molecular weight proteins.
\end{abstract}

\section{INTRODUCTION}

Whereas some marine organisms are very sensitive to certain heavy metals (e. $\mathrm{g}$. Karbe, 1972; Theede et al., 1979b) others are resistent and can accumulate them to a high degree from sea water. Their heavy-metal burden, either of the whole body or of single organs, may reflect the corresponding metal concentrations in the environment. Thus, marine bivalves have been proposed as indicator organisms for monitoring heavy-metal pollution (Schulz-Baldes, 1974; de Wolf, 1975; Phillips, 1977).

In this study of Cd uptake by Mytilus edulis, the internal distribution and loss from contaminated specimens have been analyzed. Additionally, the chemical modification and possible inactivation of the accumulated metal are considered.

In vertebrates, $\mathrm{Cd}$ is bound to mid molecular weight proteins, metallothioneins, which serve as protective proteins against acute toxicity and detrimental effects of "free" $\mathrm{Cd}$ ions on cytoplasmatic enzymes (Webb, 1975; Probst et al., 1977). Similarly, metallothioneins are responsible for primary accumulation of the metal in kidney and liver of the test animals (Tanaka et al., 1975; Overnell et al., 1977).

Olafson \& Thompson (1974) assumed a global presence of metallothioneins and in recent years their occurrence in some marine invertebrates has been established too

\footnotetext{
* Present address: Institut für Chemie und Physik an der Bundesanstalt für Milchforschung, Hermann-Weigmann-Straße 1-27; D-2300 Kiel 1, FRG
} 
(Noel-Lambot, 1976; Howard \& Nickless, 1977). Nevertheless, little is known about their function in invertebrate metabolism. Therefore, it was the aim of this study to consider the role of metallothioneins or related molecules during the accumulation of $\mathrm{Cd}$ by Mytilis edulis.

\section{MATERIALS AND METHODS}

For uptake experiments, 80 individuals (shell length 5-6 cm) were kept in 101 sea water $\left(10^{\circ} \mathrm{C}, 17 \%\right.$ S) with different Cd concentrations. The sea water was changed every second day. For metal analyses, 8 mussels were taken from each batch, and the water volume reduced by $1 \mathrm{l}$. In four mussels Cd was determined in the whole soft body; the others were dissected into the following organs: mid-gut gland, gills and pulps, kidney, mantle, foot, and adductor muscle.

Loss experiments were carried out after 18 days of Cd contamination under corresponding conditions. Mussels then were transferred to natural sea water $\left(0.1 \mu \mathrm{g} \mathrm{Cd} \mathrm{l}^{-1}\right)$, which was changed daily. All mussels were starved throughout the experiments.

Tissue samples were freeze dried and ground. Homogeneous aliquots were wet ashed in $1 \mathrm{ml} 5 \mathrm{~N} \mathrm{HNO}_{3} / 60 \% \mathrm{HClO}_{4}(2: 1)$. Cd was determined by flameless atomic absorption (Beckman Mod. 1248 fitted with an automatic background corrector).

Molecular distribution of Cd was determined in the mid-gut gland of Mytilus edulis. After 5, 9, and 16 days of contamination in $100 \mu \mathrm{g} \mathrm{Cd} 1^{-1}$ sea water, 10 individuals each were removed, mid-gut glands dissected, weighed, and homogenized in a double volume of icy $1.1 \% \mathrm{NaCl}$. Homogenates were centrifuged at $5600 \mathrm{rpm}$, the supernatants at 50,000 rpm (=126,000 g) for final pelleting. The resultant supernatant (= cytosol) was concentrated on Amicon UM O 5 ultrafiltration membranes to about $10 \mathrm{ml}$ and applied to a Sephadex G-75 column. Gel filtration was carried out with $0.05 \mathrm{M}$ Tris/HCl buffer, $\mathrm{pH}$ $8.3+1 \mathrm{M} \mathrm{NaCl}$ at room temperature. Elution was monitored at 280 and $250 \mathrm{~nm}$ (LKB UVICORD III); Cd was determined by direct injection of effluent aliquots to the graphite cuvette. To estimate the yield and quantitative distribution of protein-bound Cd, eluates were pooled, concentrated on UM O 5 ultrafiltration membranes and desalted on Sephadex G-10. Salt-free protein solutions then were freeze dried.

Comparative studies were carried out on the livers of Cd-contaminated Pleuronectes platessa, Seph. G-75 being replaced by Seph. G-50 medium.

\section{RESULTS}

Behaviour of $\mathrm{Cd}$ in the whole soft body of Mytilus edulis is summarized in Figure 1. Throughout the experiments, heavy-metal uptake is linear (Fig. 1a). Uptake rates rise significantly with increasing metal content in the medium (Fig. 1b). Up to $100 \mu \mathrm{g} \mathrm{Cd} \mathrm{^{-1 }}$ sea water, neither limitation of uptake nor any saturation process of possible membrane binding sites can be observed.

Similarly, the concentration factors change with a constant of 52 , which is true for all Cd concentrations tested (Fig. 1c).

Transfer of Cd-contaminated $M$. edulis to natural sea water results in a loss of Cd from the mussel's soft body (Fig. 1d). Contrary to the uptake, loss follows an exponential 

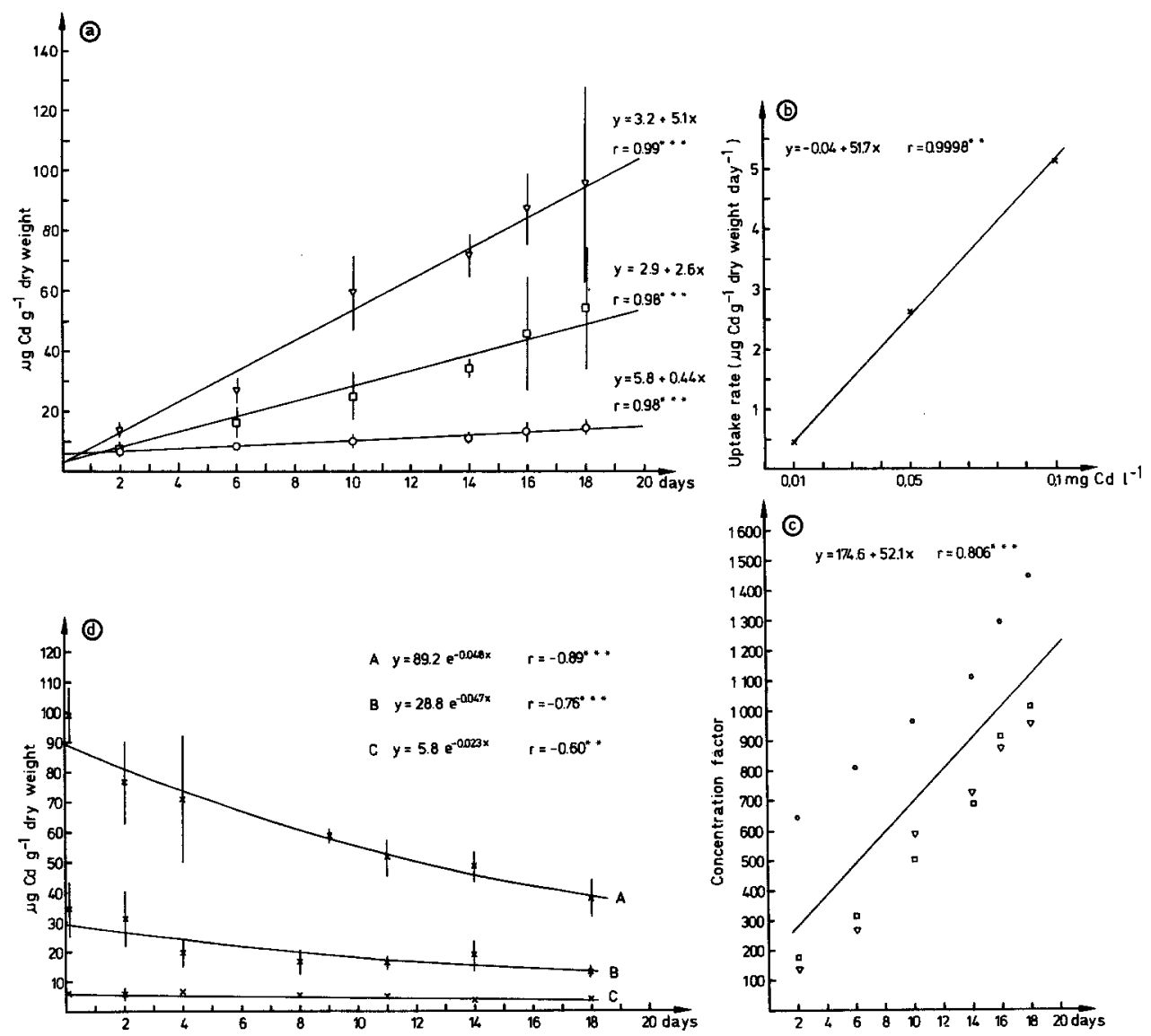

Fig. 1a-d. Mytilus edulis (shell length 5-6 cm). Behaviour of Cd in the whole soft body. a: Cd uptake at different concentrations in the external medium $\left(17 \% \mathrm{~S}, 10^{\circ} \mathrm{C}\right) ;$ b: uptake rates (slopes from regression lines in a) as function of the Cd concentration in sea water; $c$ : temporal change of the

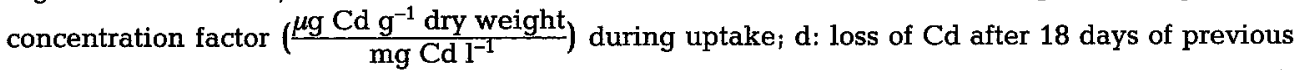
exposure to $100 \mu \mathrm{g} \mathrm{Cd}^{-1}$ (A), $50 \mu \mathrm{g} \mathrm{Cd} \mathrm{l}^{-1}$ (B), and $10 \mu \mathrm{g} \mathrm{Cd} \mathrm{l}^{-1}$ (C). Inverted triangles: $100 \mu \mathrm{g} \mathrm{Cd} \mathrm{l}^{-1}$; squares: $50 \mu \mathrm{g} \mathrm{Cd} \mathrm{l}^{-1}$; circles: $10 \mu \mathrm{g} \mathrm{Cd} \mathrm{l}^{-1}$. Significance of correlation $\mathrm{r}^{* * *}: \alpha \leqq 0.001{ }^{* * *}: \alpha \leqq 0.01$

pattern. The biological half lives, calculated by $t_{0.5}=\frac{\ln 2}{b}$, lie between 14 days for the higher and 29 days for the less contaminated specimens.

$\mathrm{Cd}$ is unequally distributed in the single organs of the mussel (Fig. 2). During uptake, the percentage distribution of $\mathrm{Cd}$ in the organs changes drastically. Thus in gills, the portion of accumulated metal rises from normally $6 \%$ of the total body burden to about $20 \%$ after 6 days in $100 \mu \mathrm{g} \mathrm{Cd} \mathrm{l}^{-1}$ and after 10 days in $50 \mu \mathrm{g} \mathrm{Cd} \mathrm{l^{-1 }}$ sea water. This primary increase is followed by a subsequent decline to nearly normal levels.

The mid-gut gland proves to be the organ with highest Cd concentrations, and its proportion of accumulated metal remains high, thereby indicating its high affinity for 

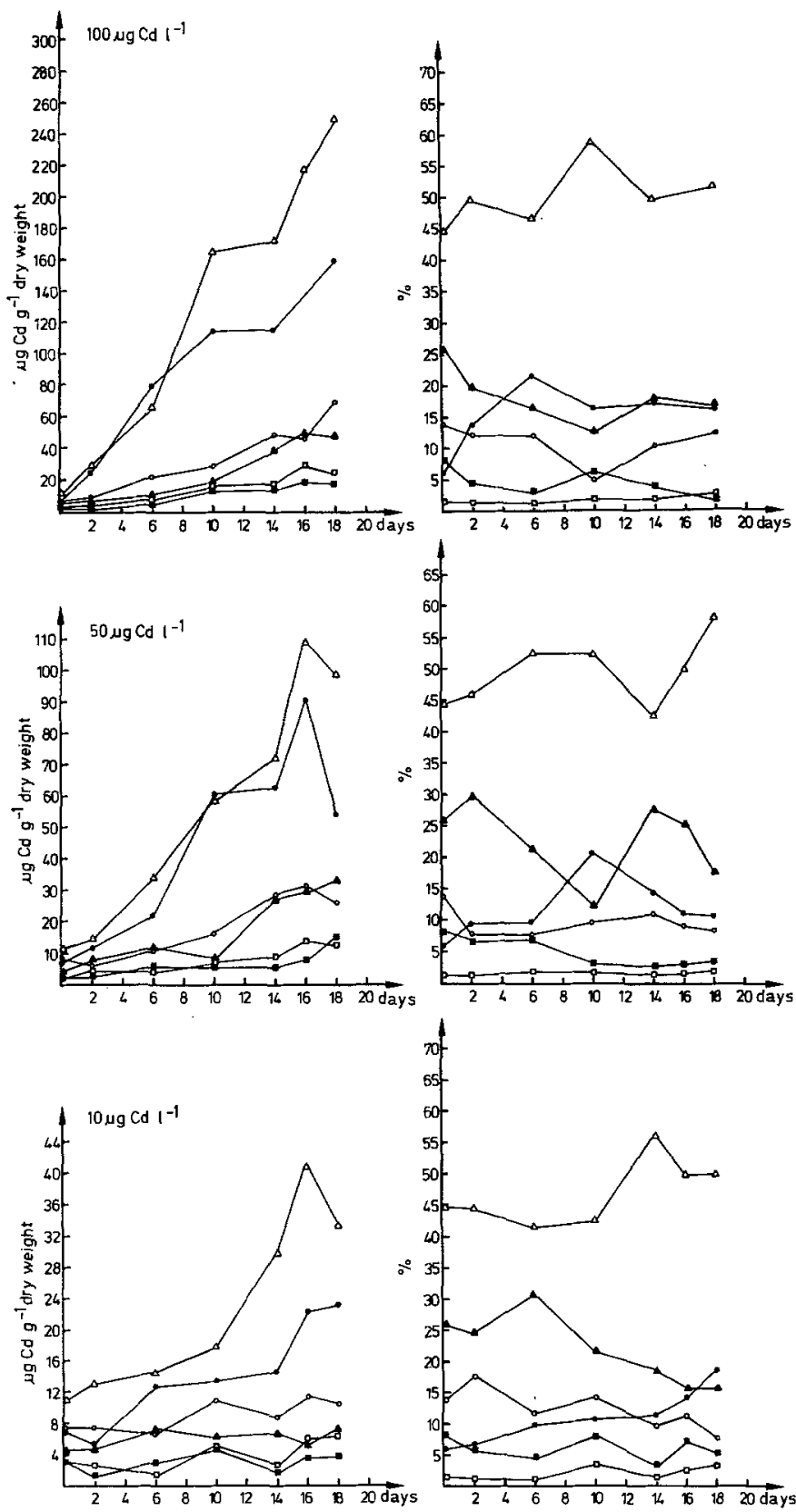

Fig. 2. Mytilus edulis (shell length 5-6 cm). Uptake of $\mathrm{Cd}$ into single organs at different $\mathrm{Cd}$ concentrations in sea water $\left(17 \% \mathrm{~S}_{1} 10^{\circ} \mathrm{C}\right)$ (left side) and percentage distribution of accumulated metal in the organs (right side). Open triangles: mid-gut gland; black circles: gills; open circles: kidney; black triangles: mantle; open squares: foot; black squares: adductor 

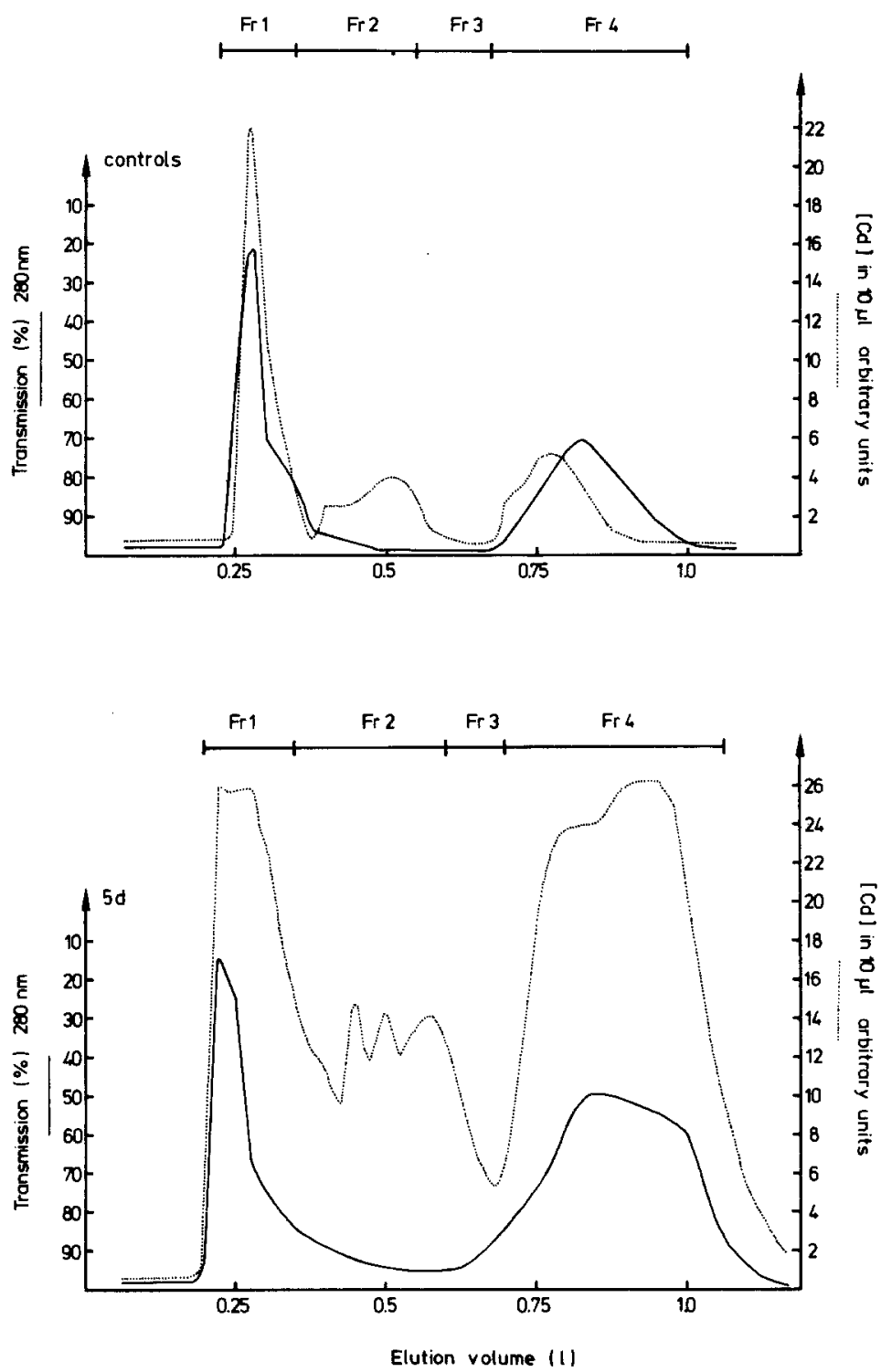

Fig. 3a. Mytilus edulis, mid-gut gland. Sephadex G-75 gel filtration of cytosols from uncontaminat-

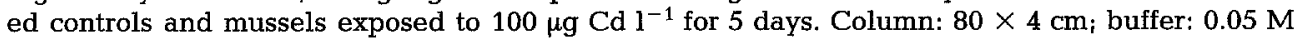
Tris/ $/ \mathrm{HCl}, \mathrm{pH} 8.3+1 \mathrm{M} \mathrm{NaCl}$

Cd. Uptake into kidney and mantle is retarded during the first few days of contamination, and there is a temporary decrease of the percentage burden.

Gel filtration studies of mid-gut gland proteins are summarized in Figure 3. Cd is eluted to different extents over the whole molecular weight range in the controls. 

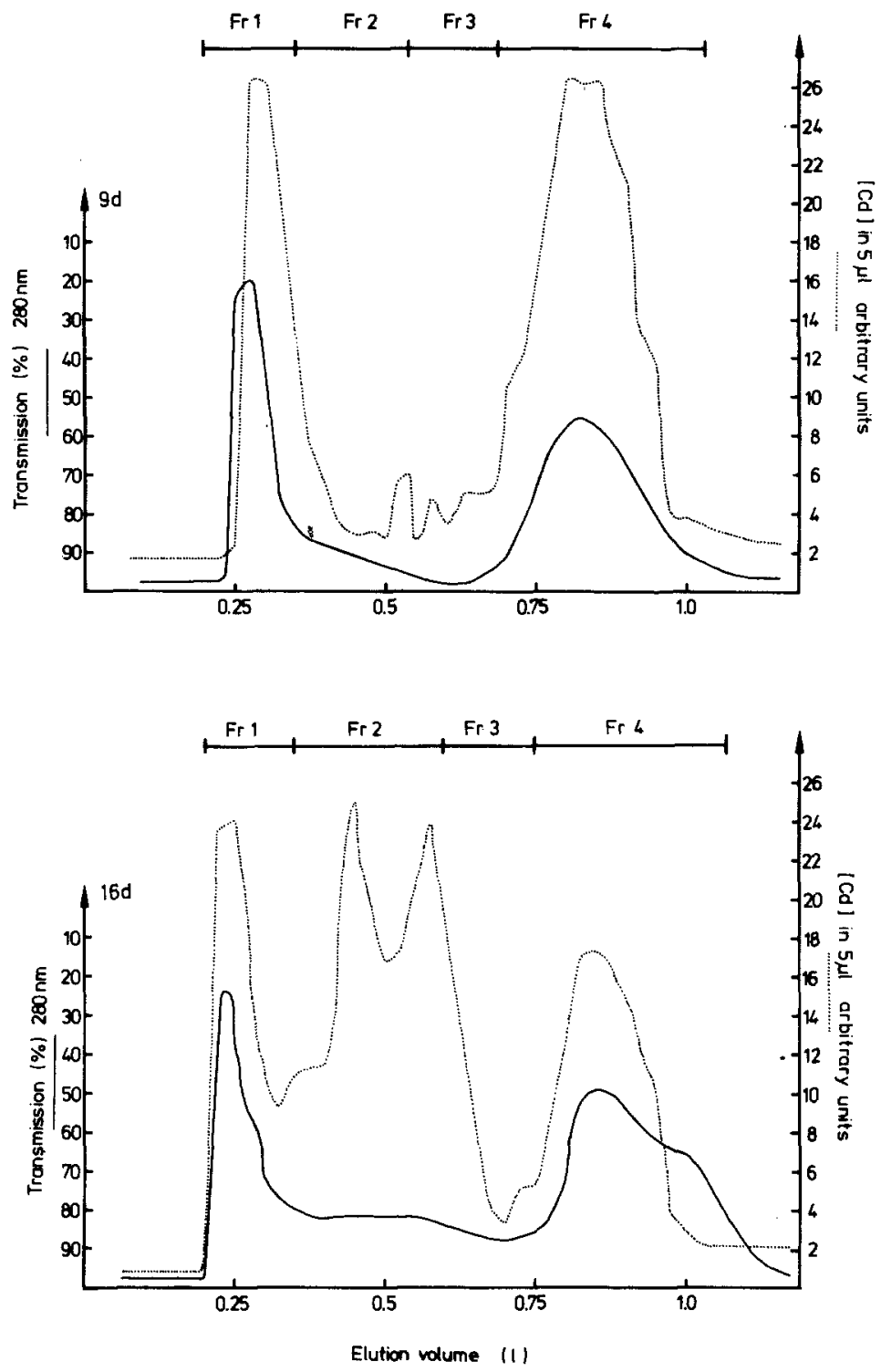

Fig. 3b. Mytilus edulis, mid-gut gland. Sephadex G-75 gel filtration of cytosols from mussels exposed to $100 \mu \mathrm{g} \mathrm{Cd} \mathrm{l}^{-1}$ for 9 and 16 days

Subsequent Cd contamination results in an increase of absorption signals in Fr 1 (high molecular weight range) and Fr 4 (low molecular weight range). Additionally, a differentiation of Cd indicating peaks in Fr 2 and Fr 3 can be observed; after 5 days of contamination this leads to three distinct peaks, corresponding to molecular weights of 
$6,600,13,200$ and 21,000 Dalton respectively. After 16 days, two pronounced Cd peaks appear in Fr 2, molecular weights correspond to 6,600 and 21,000 Dalton. Lack of absorbance at $280 \mathrm{~nm}$ indicates the absence of aromatic amino acids in this fraction.

To determine the quantitative distribution of $\mathrm{Cd}$ in the eluate, fractions were pooled as indicated, concentrated, desalted on Seph. G-10 and freeze dried. In controls, Cd concentrations are rather homogeneous (Fig. 4a), but most bound $\mathrm{Cd}(>40 \%)$ is present in Fr 1 (Fig. 4b). During contamination, most $\mathrm{Cd}$ is accumulated in the high molecular weight Fr 1. Until day 9, the amount of $\mathrm{Cd}$ in $\mathrm{Fr} 2$ and Fr 3 (mid molecular weight range) decreases significantly, but after 16 days, these fractions account for about $27 \%$ of the protein-bound metal, the concentration reaching $204 \mu \mathrm{g} \mathrm{Cd} \mathrm{g}^{-1}$ dry weight. Nearly $20 \%$ of the $\mathrm{Cd}$ is eluted in the low molecular weight range, indicating either "free" $\mathrm{Cd}$ ions or $\mathrm{Cd}$ which is probably linked to amino acids and/or amino sugars.

The total amount of the protein-bound metal however represents only $14-25 \%$ of the Cd present in the cytosol (Table 1).

In plaice liver, $\mathrm{Cd}$ is confined to only one fraction in the mid molecular weight range (Fig. 5). This is true for the controls as well as for experimentally contaminated fish. A slight increase in $250 \mathrm{~nm}$ absorption indicates mercaptide linkages. No Cd is eluted with low molecular substances. After desalting, Cd determinations of protein-bound metal
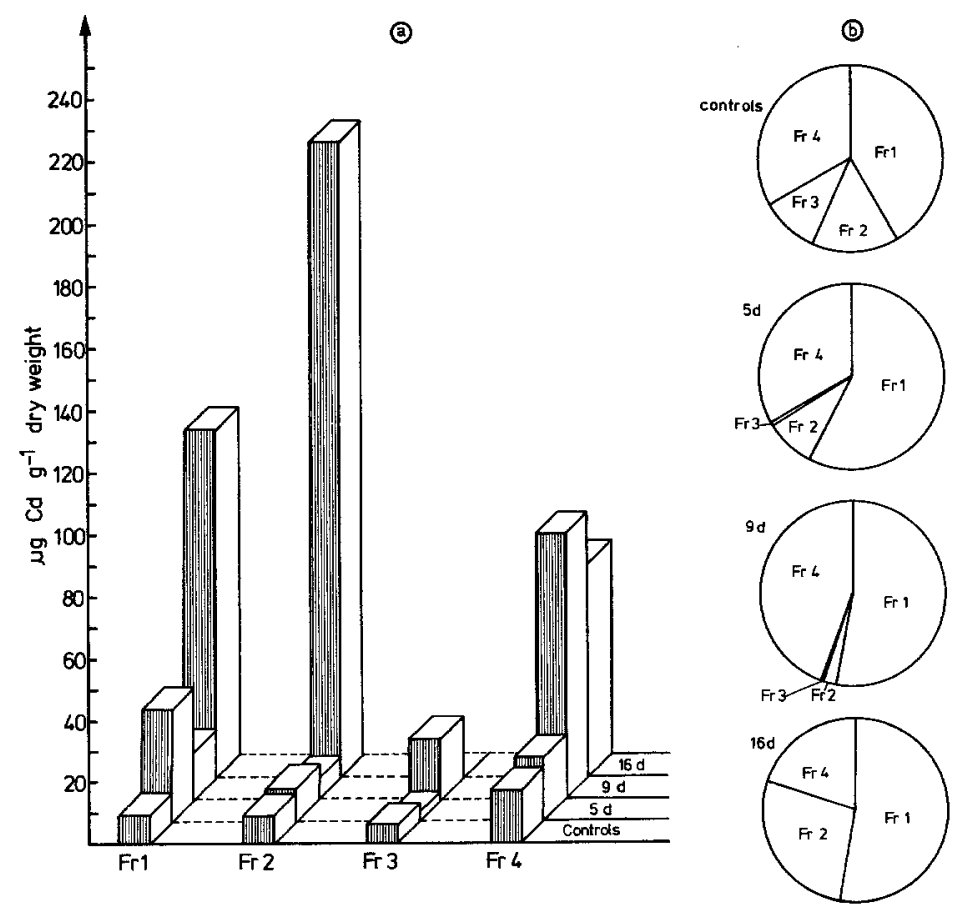

Fig. 4. Mytilus edulis, mid-gut gland. Cd concentrations in G-75 fractions after desalting on Sephadex G-10 (a), and percentage distribution of protein-bound $\mathrm{Cd}$ in the corresponding fractions (b) 

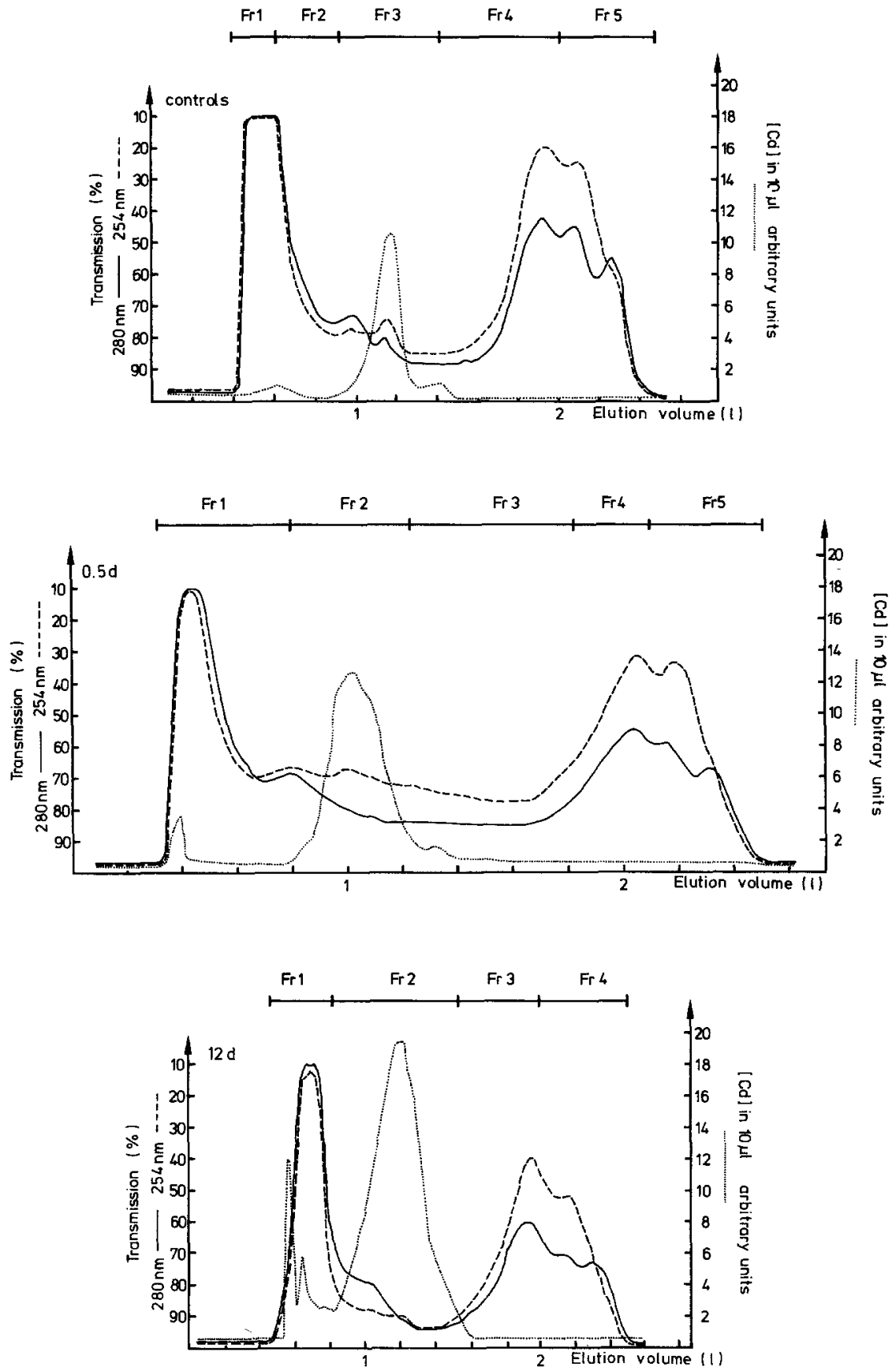

Fig. 5. Pleuronectes platessa, liver. Sephadex G-50 medium gel filtration of cytosols of uncontaminated (controls) and fish, exposed to $100 \mu \mathrm{g} \mathrm{Cd}^{-1}$ for 0.5 days and 12 days, respectively. Column: $80 \times 4 \mathrm{~cm}$; buffer $0.05 \mathrm{M}$ Tris/ $\mathrm{HCl}, \mathrm{pH} 8.3+1 \mathrm{M} \mathrm{NaCl}$ 
Table 1. Mytilus edulis, mid-gut gland. Yield of protein-bound Cd in desalted G-75 fractions in relation to the $\mathrm{Cd}$ content of cytosols. Prior to $\mathrm{Cd}$ analyses in cytosols, whole mussels were exposed

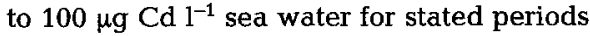

\begin{tabular}{|cccc|}
\hline $\begin{array}{c}\text { Exposure time } \\
(\mathrm{d})\end{array}$ & $\begin{array}{c}\text { Cd in cytosol } \\
(\mu \mathrm{g})\end{array}$ & $\begin{array}{c}\text { Protein-bound Cd } \\
(\mu \mathrm{g})\end{array}$ & $\begin{array}{c}\text { Yield } \\
(\%)\end{array}$ \\
\hline 0 & 6.8 & 1.6 & 23.5 \\
5 & 49 & 11 & 22.4 \\
9 & 92 & 13 & 14.1 \\
16 & 102 & 2.5 & 24.5 \\
\hline
\end{tabular}

Table 2. Pleuronectes platessa, liver. Yield of protein-bound Cd in desalted G-50 medium fractions in relation to the Cd content of the cytosols. Prior to Cd analyses, plaice were exposed to $100 \mu \mathrm{g}$ $\mathrm{Cd}^{-1}$ sea water for stated periods

\begin{tabular}{|cccc|}
\hline $\begin{array}{c}\text { Exposure time } \\
(\mathrm{d})\end{array}$ & $\begin{array}{c}\text { Cd in cytosol } \\
(\mu \mathrm{g})\end{array}$ & $\begin{array}{c}\text { Protein-bound Cd } \\
(\mu \mathrm{g})\end{array}$ & $\begin{array}{c}\text { Yield } \\
(\%)\end{array}$ \\
\hline 0 & 1.7 & 1.6 & 94.1 \\
0.5 & 5.9 & 5.6 & 94.9 \\
12.0 & 11.9 & 11.1 & 93.3 \\
\hline
\end{tabular}

(a)

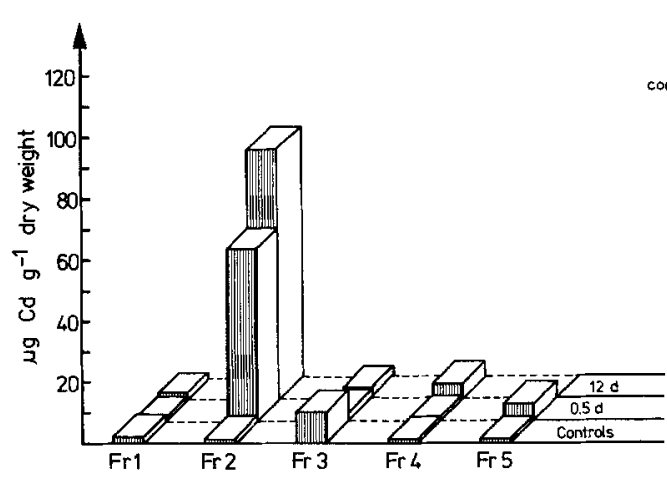

(1)

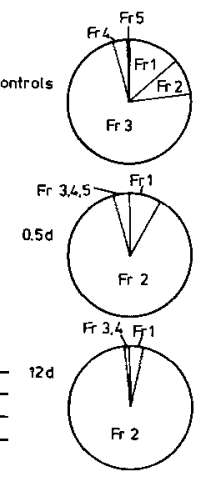

Fig. 6. Pleuronectes platessa, liver. Cd concentrations in G-50 medium fractions after desalting on Sephadex G-10 (a), and percentage distribution of protein-bound Cd in the corresponding fractions (b)

confirm the distinct accumulation in one single fraction, which contains between 72 and $95 \%$ of the total Cd (Fig. 6a, b). Moreover, about $94 \%$ of the Cd present in the cytosols is bound to proteins (Table 2).

On this basis, an effective protective function for the enzyme-containing pool can be expected. 


\section{DISCUSSION}

Uptake and accumulation of $\mathrm{Cd}$ from sea water were investigated in Mytilus edulis.

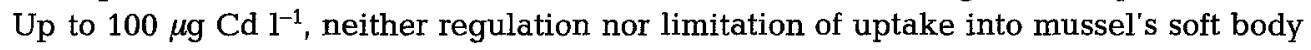
can be observed, indicating simple diffusion of $\mathrm{Cd}$ across the body surface. Uptake saturation processes, observed at about $1,500 \mu \mathrm{g} \mathrm{Cd}^{-1}$ (George \& Coombs, 1977) and inhibition of $\mathrm{Cd}$ uptake by Ca ions as described by Wright (1977) for Carcinus maenas indicate at least a mediated Cd transport across cell membranes, but obviously can be neglected under slightly elevated $\mathrm{Cd}$ concentrations in sea water.

The uptake and subsequent loss of the metal point to the existence of an equilibrium state under normal conditions in the biotope. Under these conditions, a concentration factor of 30,000 can be calculated for $M$. edulis (after values from Theede et al., 1979a). As the daily change of the concentration factor doubles in mussels additionally fed during contamination (Janssen \& Scholz, 1979) and assuming an overall linear Cd uptake, the time to reach a new equilibrium state at elevated concentrations can be calculated to be about 300 days. This is of the same order of magnitude that SchulzBaldes (1974) has determined during lead uptake in $M$. edulis.

In response to $\mathrm{Cd}$ poisoning, the formation of mid molecular weight $\mathrm{Cd}$ binding proteins, metallothioneins, is well established in vertebrates (Kägi \& Vallee, 1960; Squibb et al., 1976). Metallothioneins have virtually no aromatic amino acids and a high cystein content $(>30 \%$ ); their role as protection agents is undisputed in principle (Webb, 1975; Probst et al., 1977).

As can be seen during uptake of $\mathrm{Cd}$ in the soluble proteins of plaice liver, the metal is restricted to a single mid molecular weight fraction, containing a Cd-binding glycoprotein with properties similar to those of metallothioneins (Overnell et al., 1977). Thus, a protection of the "enzymatic pool" is evident.

Metallothioneins have been found in some invertebrates too (Noel-Lambot, 1976, 1979, Howard \& Nickless, 1977; Noel-Lambot et al., 1978). However, their significance for $\mathrm{Cd}$ detoxification in these animals is unknown. In the present study, three Cdindicating peaks corresponding to the elution volumes of proteins of $6,600,13,200$, and 21,000 Dalton could be established. The absence of aromatic amino acids in these fractions point to metallothionein-like proteins. Nevertheless, more than $50 \%$ of the protein-bound $\mathrm{Cd}$ is associated with high molecular weight proteins, so that specific and strong interaction of $\mathrm{Cd}$ with special detoxification proteins in $M$. edulis is unlikely. This is underlined by the small yield of protein-bound $\mathrm{Cd}$ after the fractionation steps.

These points indicate functional differences in the action of metallothioneins from vertebrates and corresponding proteins from $M$. edulis. Thus, in the latter, the formation of metallothionein-like proteins cannot sufficiently explain the tolerance to extraordinarily high $\mathrm{Cd}$ concentrations in the mid-gut gland. Supplementary immobilisation of $\mathrm{Cd}$ in phagolysosomes in the digestive cells of the mid-gut gland of $M$. edulis (Janssen \& Scholz, 1979) surely serves as a more effective protective mechanism, and at the same time could explain the relatively short biological half life of this metal in the common mussel. In vertebrates, Cd half lives (compiled by Friberg et al., 1976) lie one order of magnitude above the values obtained for $M$. edulis, likewise confirming functional differences between metallothioneins of vertebrates and those of $M$. edulis. 
Acknowledgements. This study forms part of the author's dissertation. His thanks are due to Prof. Dr. $H$. Theede for continuing support of this project and critical remarks on the manuscript. The research was supported by a grant from the Deutsche Forschungsgemeinschaft (DFG - Th 158/13).

\section{LITERATURE CITED}

Friberg, L., Piscator, H., Nordberg, G. F. \& Kjellström, T., 1976. Cadmium in the environment. CRCPress, Cleveland, Ohio, 248 pp.

George, S. G. \& Coombs, T. L., 1977. The effects of chelating agents on the uptake and accumulation of cadmium by Mytilus edulis. - Mar. Biol. 39, 261-268.

Howard, A. G. \& Nickless, G., 1977. Heavy metal complexation in polluted molluscs. I. Limpets (Patella vulgata and Patella intermedia). - Chem.- biol. Interact. 16, 107-114.

Janssen, H. H. \& Scholz, N., 1979. Uptake and cellular distribution of cadmium in Mytilus edulis. Mar. Biol. 55, 133-141.

Kägi, J. H. R. \& Vallee, B. L., 1960. Metallothionein: a cadmium and zinc containing protein from equine renal cortex. - J. biol. Chem. 235, 3460-3465.

Karbe, L., 1972. Marine Hydroiden als Testorganismen zur Prüfung der Toxizität von Abwasserstoffen. Die Wirkungen von Schwermetallen auf Kolonien von Eirene viridula. - Mar. Biol. 12, 316-328.

Noel-Lambot, F., 1976. Distribution of cadmium, zinc, and copper in the mussel Mytilus edulis. Existence of cadmium-binding proteins similar to metallothionein. - Experientia 32, 324-326.

Noel-Lambot, F., 1979. Cadmium accumulation correlated with increase in metallothionein concentration in the limpet Patella caerulea. In: Animals and environmental fitness. Reprints of abstracts. Ed. by R. Gilles. Pergamon Press, Oxford, 83-84.

Noel-Lambot, F., Bouquegneau, J. M., Frankenne, F., \& Disteche, A., 1978, Le role metallothioneines dans le stockage des métaux lourds chez les animaux marins. - Revue int. Océanogr. méd. 44, 13-20.

Olafson, R. W. \& Thompson, J. A. J., 1974. Isolation of heavy metal binding proteins from marine vertebrates. - Mar. Biol. 28, 83-86.

Overnell, J., Davidson, J. A. \& Coombs, T. L., 1977. A cadmium binding glycoprotein from the liver of the plaice (Pleuronectes platessa). - Biochem. Soc. Trans. 5, 267-269.

Phillips, D. J. H., 1977. The use of biological indicator organisms to monitor trace metal pollution in marine and estuarine environments - a review. - Environ. Pollut. 13, 281-317.

Probst, G. S., Bousquet, W. T. \& Miya, T. S., 1977. Correlation of metallothionein concentrations with acute cadmium toxicity in the mouse. - Toxic. appl. Pharmac. 39, 61-69.

Schulz-Baldes, M., 1974. Lead uptake from sea water and food, and lead loss in the common mussel, Mytilus edulis. - Mar. Biol. 25, 177-193.

Squibb, K. S., Cousins, R. J., Silbon, B. L. \& Levin, S., 1976. Liver and intestinal metallothionein: function in acute cadmium toxicity. - Exp. mol. Path. 25, 163-171.

Tanaka, K., Sueda, K., Onosaka, S. \& Okahara, K., 1975. Fate of ${ }^{109} \mathrm{Cd}-1$ abelled metallothionein in rats. - Toxic. appl. Pharmac. 33, 258-266.

Theede, H., Andersson, I. \& Lehnberg, W., 1979a. Cadmium in Mytilus edulis from German coastal waters. - Meeresforsch. 27, 147-155.

Theede, H., Scholz, N. \& Fischer, H., 1979b. Temperature and salinity effects on the acute toxity of cadmium to Laomedea loveni (Hydrozoa). - Mar. Ecol. Prog. Ser. 1, 13-19.

Webb, M., 1975. Metallothionein and the toxicity of cadmium. In: Ecological toxicology research. Ed. by A. D. McIntyre \& C. F. Mills. Plenum Press, New York, 177-186.

Wolf, P. de, 1975. Mercury content of mussels from West European coasts. - Mar. Pollut. Bull. 6, $61-63$.

Wright, D. A., 1977. The effect of calcium on cadmium uptake by the shore crab Carcinus maenas. J. exp. Biol. 67, 163-173. 